\title{
Characterization of the Coal Derived Humic Acids from Mukah, Sarawak as Soil Conditioner
}

\author{
Sim Siong Fong ${ }^{*, a}$ Lau Seng, ${ }^{a}$ Wong Nan Chong, ${ }^{b}$ Janice Asing, ${ }^{b}$ Muhammad Faizal b Md Nor ${ }^{a}$ \\ and Amira Satirawaty bt Mohd Pauzan ${ }^{a}$ \\ ${ }^{a}$ Faculty of Resource Science \& Technology, University Malaysia Sarawak 94300 Kota Samarahan, Sarawak \\ ${ }^{b}$ Malaysian Agricultural Research and Development Institute, Kuala Lumpur
}

\begin{abstract}
Na Malásia encontram-se abundantes reservas de carvão em Sarawak e Sabah. A utilização dessas reservas, até agora, ocorre principalmente para produção de energia. O uso não-energético como condicionador de solo ainda é inexplorado. Assim, este estudo foca a caracterização de ácidos húmicos presentes no carvão de Mukah e a avaliação de suas propriedades como condicionador de solo. Os ácidos húmicos presentes em carvão regenerados foram também avaliados. Os resultados revelaram que diferentes extratores influenciam as propriedades dos ácidos húmicos. A extração com $\mathrm{KOH} 0,5 \mathrm{~mol} \mathrm{~L}^{-1}$ produziu carvões com baixo teor de cinzas e alto teor de grupos ácidos funcionais, que são importantes como condicionadores de solo. No entanto, o rendimento foi baixo. Amostras de carvão regenerado com ácidos nítricos aumentam o rendimento em $83,45 \%$ em média. A acidez dos grupos funcionais nitro-húmicos foi aumentada mantendo-se a quantidade de cinza em nível mínimo.
\end{abstract}

In Malaysia, abundant coal resources were found in Sarawak and Sabah. The utilization of coal resources, to date, is emphasized on the energy productions. The non-energy utilization as soil conditioner is unexplored. Therefore, this study attempted to characterize the coal humic acids extracted from Mukah coal and to evaluate its properties as soil conditioner. The coal humic acids from the regenerated sample were also assessed. The results revealed that different extractants and concentrations influenced the properties of humic acids. The extraction with $\mathrm{KOH}$ at $0.5 \mathrm{~mol} \mathrm{~L}^{-1}$ produced humic acids with low ash content and high acidic functional groups, which are substantial as soil conditioner. However, the yield was low. Regeneration of coal sample with $10 \%$ nitric acids improved the yield to an average of $83.45 \%$. The acidic functional groups of nitrohumic acids were improved with the ash content remained at a low level.

Keywords: coal, humic acids, nitrohumic acids, regenerated

\section{Introduction}

Coal forms from the accumulation of vast quantities of plant remains. Formation of coal initially involves formation of peat in waterlogged environments. The peat later becomes overlain by sediments and subjected to moderate temperature and high tectonic pressure. Over geological periods of time, lignite, brown coal and bituminous coals of increasing maturity are formed. ${ }^{1}$ Coal particularly lowgrade coal, is known to be one of the resources rich in humic acids. The humic acids can be found in various environments such as soils, natural waters, rivers, lakes, sea sediment plants, peat and composts however, none of

* e-mail: sfsim@ frst.unimas.my these resources are as abundant as low-grade coal. The lowgrade coal recorded $40-85 \%$ of humic substances compare to black peat, $10-40 \%$; sapropel peat, $10-20 \%$; brown coal, $10-30 \%$, compost, $2-5 \%$, soil and sludge, $1-5 \%$.

Humic acids were reported in numerous researches as an excellent natural and organic way to provide plants and soil with a concentrated dose of essential nutrients, vitamins and trace elements. Addition of humic substances extracted from an oxidized coal to soil was found to retard the onset of runoff process under rainfall. ${ }^{2}$ Furthermore, an increase of soil cation exchange capacity, $\mathrm{pH}$ and organic matter was observed after incorporation of coal derived humic acids on two Nigerian nutrient poor tropical soils. ${ }^{3}$ The impacts of these improvements were reflected in higher crop productivity. Nevertheless, the principal 
properties and its potential application depend strongly on the origin and the isolation procedures. For example, similar formations of leonardite deposits have been discovered throughout the world, each with varying characteristics. Sources with little humic content, high ash content and lesser oxygen functional groups are not an ideal source for agricultural humic acids.

Coal resources in Malaysia to date are estimated at about 1,050 million tones. The known resources may be categorized into 231.85 million tones proven reserve; 171.38 million tones indicated reserve and 646.84 million tones inferred reserve. Of the total amount, coal resources are mainly found in Sarawak and Sabah with $69 \%$ and $29 \%$, respectively. ${ }^{4}$ The quality of the coal resources may range from lignite to anthracite; bituminuous to subbituminuous. To date, the utilization of coal resources is specifically for energy generation. An estimated 300,000 tonnes of coal from Merit-Pila Field was produced for Sejingkat Power Plant in Sarawak in 1999. The non-energy utilization of the coal resources as soil conditioner remains unexplored. Therefore, the objectives of this study are to extract and to characterize humic acids derived from the indigenous coal and to assess the suitability of the extracted humic acids as soil conditioner.

\section{Experimental}

\section{Extraction of humic acids}

Alkali extraction. Mukah coal sample was pulverized, washed and sieved through $50 \mu \mathrm{m}$ sieve to eliminate the coal dust. The retained coal sample was oven-dried at $105^{\circ} \mathrm{C}$ overnight. $10 \mathrm{~g}$ of the coal sample was added to $100 \mathrm{~mL}$ of $\mathrm{NaOH}(0.1$ mol L ${ }^{-1}$ ) and was heated to $70{ }^{\circ} \mathrm{C}$ for $2 \mathrm{~h}$. The supernatant was filtered through $50 \mu \mathrm{m}$ sieve and the coal residue was washed with distilled water until the washed water was clear. The coal residue was dried at $105{ }^{\circ} \mathrm{C}$ and weighed. The supernatant was acidified with concentrated $\mathrm{H}_{2} \mathrm{SO}_{4}$ to $\mathrm{pH} 1$ 2 and allowed to stand overnight. The precipitated humic acids were separated by centrifugation at $6,000 \mathrm{rpm}$ for 10 $\min$. The humic acids were washed with distilled water and centrifuged for twice. The gel-liked humic acids were ovendried at $60{ }^{\circ} \mathrm{C}$ and stored in desiccators. The procedure of extraction was repeated with $0.5 \mathrm{~mol} \mathrm{~L}^{-1}$ and $1.0 \mathrm{~mol} \mathrm{~L}^{-1}$ of $\mathrm{NaOH}$ and $0.1 \mathrm{~mol} \mathrm{~L}^{-1}, 0.5 \mathrm{~mol} \mathrm{~L}^{-1}$ and $1.0 \mathrm{~mol} \mathrm{~L}^{-1}$ of $\mathrm{KOH}$ according to the International Humic Substances Society, 1983 with modifications. ${ }^{5}$

Nitration of coal. The coal sample was oxidized to produce regenerated coal prior to extraction in attempt to improve the yield of humic acids. The regenerated coal was obtained by nitrating the coal sample with nitric acids at $5 \%, 10 \%$ and $20 \%$ ( $1 \mathrm{~g}$ of coal with $5 \mathrm{~mL}$ of nitric acids) at $70{ }^{\circ} \mathrm{C}$ for $2 \mathrm{~h}$ with continuous stirring. The coal sample was dried in oven at $60^{\circ} \mathrm{C}$. The nitrated coal was subjected to the alkaline extraction and the resulting extracts were referred to as nitrohumic acids.

Yields. The yield of humic acids was calculated as the weight of extracted humic acids per unit weight of coal.

\section{Characterization of humic acids}

Moisture. The moisture content was determined by drying the samples at $105{ }^{\circ} \mathrm{C}$ overnight. The ash content was determined by combustion of samples at $800{ }^{\circ} \mathrm{C}$ for $2 \mathrm{~h} .{ }^{6}$

Total acidity, carboxylic and phenolic content. The total acidity was measured using the barium hydroxide method and the carboxyl groups were determined by using calcium acetate. The phenolic content was calculated as the difference between the total acidity and the carboxyl groups. ${ }^{7}$

Total nitrogen content. The nitrogen content was analyzed with Kjeldahl digestion procedure. ${ }^{8}$

FTIR analysis. FTIR spectra of the samples were recorded on $\mathrm{KBr}$ pellets ( $2 \mathrm{mg}$ humic acids and $100 \mathrm{mg} \mathrm{KBr}$ ) using a Shidmadzu Series FTIR spectrophotometer. All of the spectra were self-deconvoluted to improve the apparent resolution.

$U V$-Vis analysis. Approximately $5.0 \mathrm{mg}$ of humic acids samples were dissolved in $25 \mathrm{~mL}$ of $0.05 \mathrm{~mol} \mathrm{~L}^{-1} \mathrm{NaHCO}_{3}$ solutions with $\mathrm{pH}$ adjusted to 8-9 with $0.1 \mathrm{~mol} \mathrm{~L}^{-1} \mathrm{NaOH}$ to assist solubility. Absorbances at $400 \mathrm{~nm}, 465 \mathrm{~nm}, 600$ $\mathrm{nm}$ and $665 \mathrm{~nm}$ were recorded. The $\mathrm{E}_{4} / \mathrm{E}_{6}$ value was calculated based on the ratio of absorbance at $465 \mathrm{~nm}$ and $665 \mathrm{~nm}$. Absorbance at $465 \mathrm{~nm}$ expresses presence of humic acids formed in initial humification stage and absorbance at $665 \mathrm{~nm}$ indicates presence of humic acids formed in well-humified organic matter. ${ }^{9}$ The value of $\Delta$ $\log \mathrm{K}$ coefficient, $\Delta \log \mathrm{K}=\log \mathrm{A}_{400}-\log \mathrm{A}_{600}$, was calculated to categorize the degree of humification. ${ }^{10}$

\section{Results and Discussion}

\section{Extraction of humic acids}

Table 1 summarizes the extraction yield of humic acids with $\mathrm{NaOH}$ and $\mathrm{KOH}$ at varying concentrations. Generally, the yield of humic acids was increased with the 
concentration of alkaline solution. The trend may be attributed to the increase in the solubility of humic acids with $\mathrm{pH} .{ }^{11}$ Yates and Von Wandruszka, ${ }^{12}$ reported an increase in surface tension with concentration of $\mathrm{Na}^{+}$, which indicated that humic solute was more anionic and therefore hydrophilic at higher molarity. The present results also revealed greater extraction efficiency with $\mathrm{KOH}$. It has been well established that $\mathrm{KOH}$ is a more efficient extractant for humic acids. Garcia et al., ${ }^{13}$ compared the extraction efficiency with $\mathrm{NaOH}, \mathrm{KOH}$ and $\mathrm{Na}_{4} \mathrm{P}_{2} \mathrm{O}_{7}$, revealed the greatest yields with $0.25 \mathrm{~mol} \mathrm{~L}^{-1} \mathrm{KOH}$. The observation was likewise supported by Rocha et al. ${ }^{14}$ The solubility of humic substances involves dissociation, molecular expansion and solvent penetration. $\mathrm{KOH}$ possess a greater efficiency, as the ionic radius of hydrated $\mathrm{K}^{+}\left(300 \times 10^{-9} \mathrm{~m}\right)$ is smaller in relation to hydrated $\mathrm{Na}^{+}\left(450 \times 10^{-9} \mathrm{~m}\right)$. This allows a greater expansion, counterbalance and capacity of interaction of the intra and intermolecular charges present in the humic substances. ${ }^{14}$ Generally, the maximum extraction yield was obtained at an average of $20 \%$ with $\mathrm{KOH}$. Re-extraction of humic acids produced an average yield of $<2 \%$ from 0.5 and $1.0 \mathrm{~mol} \mathrm{~L}^{-1}$ of $\mathrm{KOH}$ which, did not reflect a significant improvement on the yield. The essential yield of humic acids is economically insufficient as the soil conditioner. In comparison to leornadite marketed elsewhere (contains average of $80 \%$ of humic acids), the humic acids extracted from the indigenous coal were far too little for economically sustainable exploitation. However, pretreatment of the coal samples with $10 \%$ of nitric acids $\left(\mathrm{HNO}_{3}\right)$ improved the yield tremendously to an average of $83.45 \%$. Improvement as such was also reported in the study by Won, ${ }^{15}$ as the yield of nitrohumic acids was 5 times (by weight) more than the original humic acids. The role of $\mathrm{HNO}_{3}$ in regeneration process was to manipulate the solubility of humic acids by introducing acid groups from $\mathrm{HNO}_{3}$ to enable them more readily attacked during extraction. Therefore, the yield of humic acids is governed by the concentration of $\mathrm{HNO}_{3}$. The present study revealed

Table 1. Yield of humic acids under different extraction conditions

\begin{tabular}{lcr}
\hline Extraction conditions & $\begin{array}{c}\text { Concentration } \\
\left(\mathrm{mol} \mathrm{L}^{-1}\right)\end{array}$ & $\begin{array}{r}\text { Yield } \\
(\%)\end{array}$ \\
\hline $\mathrm{NaOH}$ & 0.1 & 3.61 \\
& 0.5 & 9.83 \\
$\mathrm{KOH}$ & 1.0 & 13.67 \\
& 0.1 & 3.43 \\
& 0.5 & 16.00 \\
Regenerated with $5 \% \mathrm{HNO}_{3}$, extracted with $\mathrm{KOH}$ & 0.5 & 20.00 \\
Regenerated with $10 \% \mathrm{HNO}_{3}$, extracted with $\mathrm{KOH}$ & 0.5 & 83.00 \\
Regenerated with $20 \% \mathrm{HNO}_{3}$, extracted with $\mathrm{KOH}$ & 0.5 & 65.10 \\
\hline
\end{tabular}

that application of $10 \%$ of $\mathrm{HNO}_{3}$ has optimized the extraction yield.

\section{Chemical characteristics of humic acids}

Table 2 presents the chemical characteristics of humic acids extracted with $\mathrm{NaOH}$ and $\mathrm{KOH}$ at varying concentration. They were prepared from the Mukah coal containing $2.20 \%$ moisture and $0.78 \%$ ash. The moisture content in the humic acids was from the sample preparation. The ash content however may be due to the sample preparation or the origin of raw materials. The value exceeded the ash content of the raw material, indicating the contribution of residual $\mathrm{Na}_{2} \mathrm{SO}_{4} / \mathrm{K}_{2} \mathrm{SO}_{4}$ from preparation process. Nevertheless, increasing alkalinity of $\mathrm{NaOH}$ and $\mathrm{KOH}$ from $0.1 \mathrm{~mol} \mathrm{~L}^{-1}$ to $0.5 \mathrm{~mol} \mathrm{~L}^{-1}$ produced humic acids with decreasing ash content. This observation was also recorded in the study of Rosa et al. ${ }^{16}$ The ash content was augmented in the extraction with 1.0 mol L ${ }^{-1}$ of $\mathrm{KOH}$ and $\mathrm{NaOH}$. Levesque and Schnitzer ${ }^{17}$ reported high ash content in humic acids produced with $0.1-0.15 \mathrm{~mol} \mathrm{~L}^{-1} \mathrm{NaOH}$. Reduction of the ash content from $25 \%$ to $5 \%$ was achieved when $0.4 \mathrm{~mol} \mathrm{~L}^{-1} \mathrm{NaOH}$ was used. Considering the total acidity, humic acids extracted with $\mathrm{KOH}$ generally consisted more acidic functional groups (-COOH and phenolic $\mathrm{OH}$ ) compared to $\mathrm{NaOH}$. Under alkaline condition, auto-oxidation and chemical changes such as condensation between amino acids and aldehydes or quinones may take place. The occurrence of alkaline auto-oxidation processes is indicated by an increase in the $\mathrm{C}=\mathrm{O}$ groups..$^{18}$ The results obtained demonstrated a greater $\mathrm{C}=\mathrm{O}$ content in the $\mathrm{KOH}$ extracts, suggesting the promotion of alkaline auto-oxidation. The nitration process further improved the total acidity of humic acids thus enhanced its feature as soil conditioner. The oxidation process may degrade the core structure of humic acids into a variety of aliphatic dicarboxylic acids, benzenecarboxylic acids, hydroxybenzoic acids and nitro compounds such as nitrophenols, nitrobenzoic acids and dinitrosalicyclic acids. ${ }^{19}$ The presence of these compounds was reflected in the results of carboxyl and phenolic content. In addition, the nitration process substitutes the nitro and nitroso groups to phenolic structures of humic acids which was observed by the increased of nitrogen content. ${ }^{20,21}$

\section{FTIR}

The FTIR spectra of the isolated humic acids exhibited similar absorption bands as reported elsewhere (Figures 1 and 2). ${ }^{14,22,23}$ The important features of the spectra are: 
Table 2. Characteristics of humic acids with varying extractants and concentration

\begin{tabular}{|c|c|c|c|c|c|c|}
\hline \multirow[t]{2}{*}{ Extraction Condition } & \multirow[t]{2}{*}{ Moisture (\%) } & \multirow[t]{2}{*}{ Ash (\%) } & \multicolumn{3}{|c|}{ Functional groups (m equiv. $\mathrm{g}^{-1}$ ) } & \multirow[t]{2}{*}{ Nitrogen $(\%)$} \\
\hline & & & Total acidity & $-\mathrm{COOH}$ & $-\mathrm{OH}$ & \\
\hline $0.1 \mathrm{~mol} \mathrm{~L}^{-1} \mathrm{NaOH}$ & $4.44 \pm 1.93$ & $25.56 \pm 1.93$ & $6.36 \pm 0.04$ & $2.42 \pm 0.03$ & $3.95 \pm 0.06$ & $0.68 \pm 0.04$ \\
\hline $0.5 \mathrm{~mol} \mathrm{~L}^{-1} \mathrm{NaOH}$ & $18.59 \pm 2.37$ & $14.10 \pm 0.17$ & $8.17 \pm 0.05$ & $2.10 \pm 0.06$ & $6.07 \pm 0.10$ & $0.68 \pm 0.03$ \\
\hline $1.0 \mathrm{~mol} \mathrm{~L}^{-1} \mathrm{NaOH}$ & $29.04 \pm 4.73$ & $16.83 \pm 0.80$ & $7.93 \pm 0.05$ & $1.52 \pm 0.03$ & $6.41 \pm 0.05$ & $0.55 \pm 0.04$ \\
\hline $0.1 \mathrm{~mol} \mathrm{~L}^{-1} \mathrm{KOH}$ & $11.68 \pm 3.07$ & $20.39 \pm 0.34$ & $7.17 \pm 0.03$ & $1.60 \pm 0.04$ & $5.57 \pm 0.06$ & $0.65 \pm 0.04$ \\
\hline $0.5 \mathrm{~mol} \mathrm{~L}^{-1} \mathrm{KOH}$ & $8.09 \pm 1.73$ & $10.06 \pm 0.92$ & $11.49 \pm 0.04$ & $2.27 \pm 0.05$ & $9.22 \pm 0.05$ & $0.65 \pm 0.03$ \\
\hline $1.0 \mathrm{~mol} \mathrm{~L}^{-1} \mathrm{KOH}$ & $9.89 \pm 3.34$ & $23.08 \pm 7.81$ & $8.36 \pm 0.02$ & $2.76 \pm 0.03$ & $5.60 \pm 0.03$ & $0.43 \pm 0.05$ \\
\hline $\mathrm{HNO}_{3} / 0.5 \mathrm{~mol} \mathrm{~L}^{-1} \mathrm{KOH}$ & $5.42 \pm 1.82$ & $8.68 \pm 1.77$ & $11.28 \pm 0.04$ & $3.59 \pm 0.05$ & $7.69 \pm 0.04$ & $1.65 \pm 0.05$ \\
\hline
\end{tabular}

i) a weak sharp band at $3690 \mathrm{~cm}^{-1}$ which is attributed to the valence vibration of water; $i$ ) a broad band around $3400 \mathrm{~cm}^{-1}$ due to $\mathrm{O}-\mathrm{H}$ stretching of phenol and alcohol; iii) a couple of weak bands between 2920 and $2850 \mathrm{~cm}^{-1}$ attributed to $\mathrm{C}-\mathrm{H}$ aliphatic; $i v$ ) a well-defined band at 1706 $\mathrm{cm}^{-1}$ due to $\mathrm{C}=\mathrm{O}$ stretching of ketonic and carboxylic groups; $v$ ) a strong peak at $1620 \mathrm{~cm}^{-1}$ assigned to aromatic $\mathrm{C}=\mathrm{C}$ stretching, $\mathrm{C}=\mathrm{O}$ of conjugated ketones and carboxylate ions; vi) a couple of peaks at $1430 \mathrm{~cm}^{-1}$ and $1334 \mathrm{~cm}^{-1}$ due to $\mathrm{C}-\mathrm{H}$ stretching; vii) a group of low intensity bands between $1000 \mathrm{~cm}^{-1}$ and $1100 \mathrm{~cm}^{-1}$ attributed to $\mathrm{Si}-\mathrm{O}$ stretching and $\mathrm{C}-\mathrm{O}$ stretching of polysaccharides; viii) weak bands at $1040 \mathrm{~cm}^{-1}$ due to $\mathrm{S}=\mathrm{O}$ due to treatment of humic acids with sulphuric acids

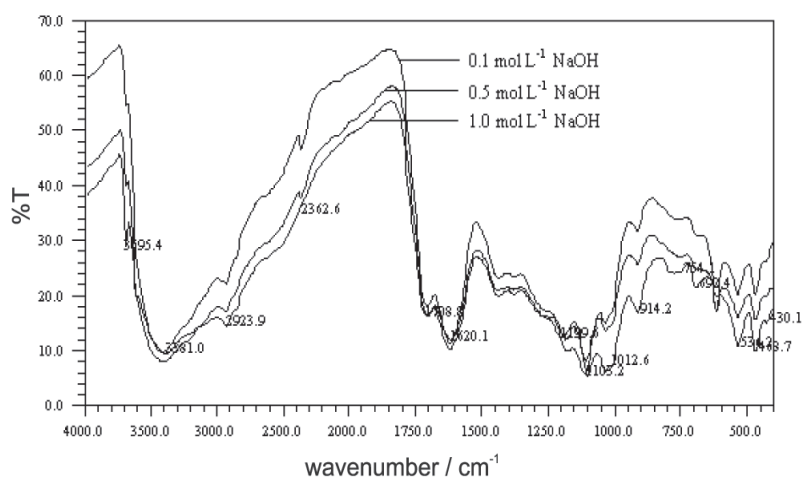

Figure 1. FTIR spectra of humic acids extracted with different concentration of $\mathrm{NaOH}$.

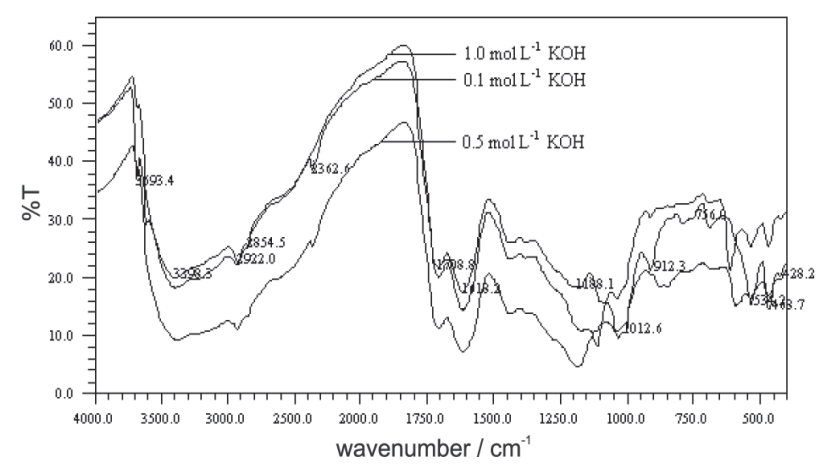

Figure 2. FTIR spectra of humic acids extracted with different concentration of $\mathrm{KOH}$. and $i x$ ) absorption bands at $470-480 \mathrm{~cm}^{-1}$ and $530-540$ $\mathrm{cm}^{-1}$, which are due to mineral components. ${ }^{19}$

The spectra show relatively more bands in the region of 400-700 $\mathrm{cm}^{-1}$; and they are greater in intensity compared to those reported in the literature. ${ }^{14,23}$ Humic acids may differ significantly with respect to their contents of inorganic constituents, which manifests in the region of 470-480 and $530-540 \mathrm{~cm}^{-1}$. The variation may be due to the differences in the extraction and purification procedures. The purification with $\mathrm{HF} / \mathrm{HCl}$ treatment, which aims at removing the ash content was not included in this study therefore the impurities due to mineral components are prominent. The humic acids prepared with $\mathrm{NaOH}$ and $\mathrm{KOH}$ demonstrated similar pattern on the IR spectra. The humic acids extracted with different molarity of $\mathrm{NaOH}$ exhibited closer similarity, suggesting an interrelated structure. The spectra of humic acids prepared with $0.1 \mathrm{~mol} \mathrm{~L}^{-1}$ and 1.0 mol L-1 of $\mathrm{KOH}$ showed a decrease in band intensities at $3400 \mathrm{~cm}^{-1}, 1700 \mathrm{~cm}^{-1}$ and $1620 \mathrm{~cm}^{-1}$. The reduction in the intensity at $1700 \mathrm{~cm}^{-1}$ may be attributed to the substitution of carbonyl groups to salts, as the humic acids prepared with $0.1 \mathrm{~mol} \mathrm{~L}^{-1}$ and $1.0 \mathrm{~mol} \mathrm{~L}^{-1} \mathrm{KOH}$ were higher in ash content. The absorption bands presented in the region of $1000-1100 \mathrm{~cm}^{-1}$ were rather shifted for humic acids extracted with $\mathrm{KOH}$. In this region, absorption bands are assigned to the presence of mineral content. It is inappropriate to be used for characterization of atomic groups as minor silicates may induce strong absorption.

Several changes due to regeneration were observed on the IR spectra of humic acids prepared from the regenerated coal: $i$ ) an additional poorly-defined shoulder at $1544 \mathrm{~cm}^{-1}$ attributed to amide II (possibly nitrogroups in humic acids oxidized by nitric acids); ii) absence of a band at $1200 \mathrm{~cm}^{-1}$ with formation of a band at $1110 \mathrm{~cm}^{-1}$ and iii) increase in band intensity at $1040 \mathrm{~cm}^{-1}$ (Figure 3). The absence of band at $1200 \mathrm{~cm}^{-1}$ (carboxylic groups) with the increase of band at $1040 \mathrm{~cm}^{-1}$ (C-N bending) suggested that the nitration might occur at the expenses of the carboxylic groups. These observations were slightly 


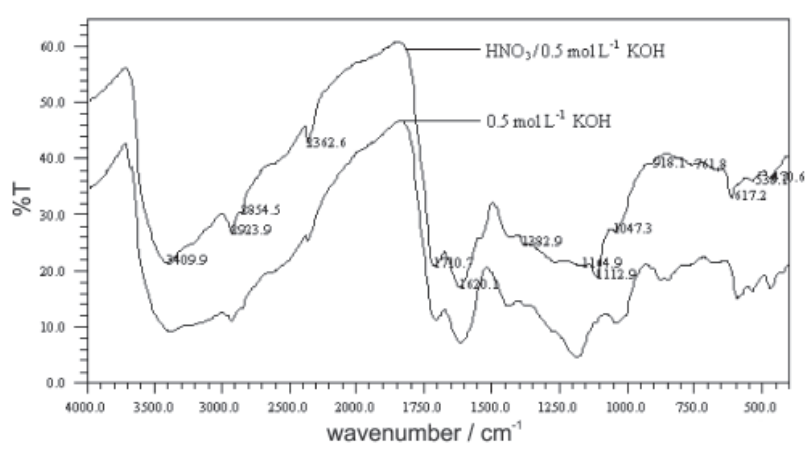

Figure 3. FTIR spectra of humic acids prepared from nitrated coal and untreated coal with $0.5 \mathrm{~mol} \mathrm{~L}^{-1} \mathrm{KOH}$.

deviated from the study of Dick et al. ${ }^{23} \mathrm{~A}$ sharp absorption band at $1530 \mathrm{~cm}^{-1}$ due to $\mathrm{NO}_{2}$ stretching which was reported as an indicative of the nitration process was not noticed in the present study.

\section{$U V$-Vis}

The $\mathrm{E}_{4} / \mathrm{E}_{6}$ coefficient is widely used in agricultural practices to express the degree of humification. A low ratio may be indicative of a relatively high degree of condensation of aromatic constituents; a high ratio infers the presence of relatively more aliphatic structures. ${ }^{19}$ The $\mathrm{E}_{4} / \mathrm{E}_{6}$ ratio is expected to decrease with increasing molecular weight.

Table 3 shows the UV-Vis spectral properties of humic acids. The $\mathrm{E}_{4} / \mathrm{E}_{6}$ ratios progresses in an increasing trend, although variably, when alkaline media with higher molarity was applied. The results demonstrated that there was a possible structure fractionation with higher concentration of alkaline media leading to a smaller molecular weight. Levesque and Schnitzer ${ }^{17}$ revealed partial fractionation in humic acids prepared with 1.0 mol L-1 $\mathrm{NaOH}$ as an increase in the $\mathrm{E}_{4} / \mathrm{E}_{6}$ ratio was observed. Rosa et al., ${ }^{16}$ investigated the parameters influencing on the humic substances extraction, inferred similar observation. In comparison to the extractant employed, the $\mathrm{E}_{4} / \mathrm{E}_{6}$ of humic acids yielded with $\mathrm{KOH}$ were relatively higher compared to those extracted with $\mathrm{NaOH}$, indicative of more aliphatic structure. This observation was in contrast to the study of Rocha $\mathrm{et} \mathrm{al.}{ }^{14}$ The nitration process on the other hand, produced humic acids with lower $\mathrm{E}_{4} / \mathrm{E}_{6}$ ratio demonstrating higher level of condensation. It was well recognized that the degradation products of oxidation process were enriched with aromatic compounds. ${ }^{24}$ Piccolo et al. ${ }^{25}$ related the plant nitrate uptake and growth regulations with the structural features of humic acids, concluded that the most effective humic fraction were those with higher acidic
Table 3. UV-Visible spectral properties of humic acids

\begin{tabular}{lccc}
\hline Preparation & $\begin{array}{c}\text { Concentration } \\
\left(\mathrm{mol} \mathrm{L}^{-1}\right)\end{array}$ & $\mathrm{E}_{4} / \mathrm{E}_{6}$ & $\Delta \log \mathrm{K}$ \\
\hline $\mathrm{NaOH}$ & 0.1 & 3.372 & 0.555 \\
& 0.5 & 3.765 & 0.572 \\
$\mathrm{KOH}$ & 1.0 & 3.709 & 0.590 \\
& 0.1 & 3.642 & 0.579 \\
& 0.5 & 3.530 & 0.566 \\
Regenerated with 10\% & 1.0 & 4.206 & 0.642 \\
$\mathrm{HNO}_{3,}$, extracted with $\mathrm{KOH}$ & 0.5 & 3.334 & 0.660 \\
\hline
\end{tabular}

functionality and smaller molecular size. The aliphatic and aromatic content of the extract did not appear to play a role.

Kumada, ${ }^{10}$ correlated the values of $\Delta \log \mathrm{K}$ coefficient and the degree of humification. On the basis of $\Delta \log \mathrm{K}$ coefficient, humic acids were divided into 3 types: type A - humic acids of high degree of humification for which the values of $\Delta \log \mathrm{K}$ coefficient is up to 0.6 ; type Bthose of corresponding values between 0.6-0.8 and type $\mathrm{R}_{\mathrm{p}}-\Delta \log \mathrm{K}$ coefficient within the range of $0.8-1.1$. No significant different was observed at $95 \%$ confidence level for $\Delta \log \mathrm{K}$ coefficient of humic acids with varying treatments. In agricultural perspective, fertilizer with higher humification degree is expected to have a better agronomic quality. Nevertheless, the differences of UVVis properties of humic acids were not significant enough to enable this parameter be used as an indicator of humification degree.

\section{Conclusions}

For agricultural purposes, there are several criteria that humic acids products shall comply. Sources with sufficient humic concentration are substantial of high economical value. Humic acids with higher acidic functional groups and lower ash content however are imperative for the effectiveness in influencing the biological activity of the plant system and soil properties. The study concluded that the extraction yield depended on the extractant and its concentration. $\mathrm{KOH}$ extraction produced a better yield compare to $\mathrm{NaOH}$. The extraction with $\mathrm{KOH}$ at $0.5 \mathrm{~mol}$ $\mathrm{L}^{-1}$ generated humic acids with higher acidic functional groups and lower ash content. However, the yield was economically inadequate therefore constraining the application of coal humic acids as soil conditioner. The nitration process enhanced the features of humic acids as soil conditioner as the yield and the acidic functional groups were improved significantly with the ash content remained low. The IR spectra of humic acids extracted with $\mathrm{KOH}$ and $\mathrm{NaOH}$ were similar. The IR spectrum of 
nitrohumic acids however revealed an additional poorlydefined shoulder at $1544 \mathrm{~cm}^{-1}$ and the disappearance of the band at $1200 \mathrm{~cm}^{-1}$ with increased band intensity at $1040 \mathrm{~cm}^{-1}$ as an indication of nitrogen incorporation. The UV-Visible spectral properties of humic acids did not demonstrate a significant different to enable this parameter dependable as indicator of humification degree.

\section{Acknowledgments}

The authors wish to thank the IRPA grant (01-03-030107EA001) and the University Malaysia Sarawak for financial support.

\section{References}

1. Lawson, G.J.; Stewart, D. In Humic Substances II: In Search of Structure; Hayes, M.H.B.; MacCarthy, P.; Malcolm, R.L.; Swift, R.S., eds.; John Wiley \& Sons: Chichester, USA, 1989.

2. Piccolo, A.; Celano, G.; Environmental Toxicity and Chemistry 1994, 13, 1737.

3. Piccolo, A.; Pietramellara, G.; Mbagwu, J.S.C.; Soil Technol. 1997, 10, 235.

4. Thaddeus, J.; Proceedings of the Joint Eighth APEC Clean Fossil Energy Technical Seminar and Seventh APEC Coal Flow Seminar, Thailand, 2000.

5. Swift, R.S. In Methods of Soil Analysis Part 3: Chemical Methods ( SSSA Book Series No.5.); Sparks, D.L. ed.; SSSA and ASA: Madison, WI, 1996.

6. Allen, S.E.; Chemical Analysis of Ecological Materials, Blackwell Scientific: London, 1989.

7. Schnitzer, M. In Proc. Symposium on Soil Organic Matter Studies, International Atomic Energy Agency: Vienne, 1977.
8. Chin, S.P.; Laboratory Manual of Methods of Soil Analysis, Agriculture Research Centre: Sarawak, 2000.

9. D’bska, B.; Maciejewska, A.; Kwiatkowska, J; Rostlinna Vybroba 2002, 48, 33.

10. Kumada, K.; Food Fertil. Technol. Cent. 1985, 22, 10.

11. Kipton, H.; Powell, J.; Town, R.M; Analytical Chimica Acta 1992, 267, 47.

12. Yates, L.M.; Von Wandruszka, R.; Soil Sci. Soc. Am. J. 1999, 63, 1645.

13. Garcia, D.; Cegarra, J.; Abad, M.; Fuel Processing Technology 1996, 48, 51.

14. Rocha, J.C.; Rosa, A.H.; Furlan, M.; J. Braz. Chem. Soc. 1998, 9, 51 .

15. Won, T.K.; Journal of the Korean Chemical Society 1968, 13, 62.

16. Rosa, H.R.; Rocha, J.C.; Furlan, M.; Quim. Nova 2000, 23, 472.

17. Levesque, M.; Schnitzer, M.; Canad. J. Soil Sci. 1965, 46.

18. Swift, R.S.; Posner, A.M.; J. Soil Sci. 1972, 23, 50.

19. Stevenson, F.J.; Humus Chemistry Genesis, Composition, Reactions, John Wiley: New York, 1982.

20. Gavilan, J.M.; Moliner, R.; Suso, J.L.; Afinidad 1982, 39, 413.

21. Patti, A.F.; Verheyen, T.V.; Douglas, L.; Wang, X.; The Science of Total Environment 1996, 113, 49.

22. Novák, J.; Kozler, J.; Janoš, P.; Čežíková, J.; Tokarová, V.; Madronová, L.; Reactive \& Functional Polymers 2001, 47, 101.

23. Dick, D.P.; Mangrich, A.S.; Menezes, S.M.C.; Pereira, B.; J. Braz. Chem. Soc. 2002, 13, 177.

24. Orlov, D.S.; Humus Acids of Soils, Oxonian Press Pvt. Ltd: New Delhi, 1985.

25. Piccolo, A.; Nardi, S.; Concheri, G.; Soil Biology and Biochemistry 1992, 24, 373. 